\title{
有効地震動の計算式とその実測例による検討

\author{
MODEL OF THE EFFECTIVE SEISMIC MOTIONS OF EMBEDDED \\ FOUNDATION AND ITS VERIFICATION BY OBSERVED DATA
}

\author{
原田隆典* · 久保慶三郎** ・片 山恒 雄*** \\ By Takanori HARADA, Keizaburo KUBO and Tsuneo KATAYAMA
}

\begin{abstract}
With the aid of currently available finite element method results, an approximate analytical solution is developed for the effective seismic motions of cylindrical embedded rigid foundations having the two embedment cases as follows : Case 1 ; embedded in a viscoelastic surface layer with the foundation base resting on a much stiffer bedrock, Case 2 ; embedded in a viscoelastic surface layer with the foundation base resting within the surface layer. The characteristics of the solution are compared with the results of the laboratory tests by shaking table and also with the responses observed at an actual embedded foundation during an earthquake, where the original data were available by other investigators. It is found from the comparisons that the solution developed in this paper well agrees with the experimental and observed data.
\end{abstract}

\section{1. まえがき}

有効地震動とは, 基礎の幾何学条件により, 基礎周辺 地盤の地震動が拘束され変形されるために生ずる地震動 で，図一1のような基礎-地盤系を等価な剛体 2 自由度モ デルに置換するときの入力地震動 $u_{G}^{\prime}, \varphi^{\prime}$ となる. 物理 的には, “質量が零の基礎の地震応答値”と定義され る1) 3). したがって, この有効地震動を観测によって直 接とらえるためには, 質量効果の小さい地中構造物を用

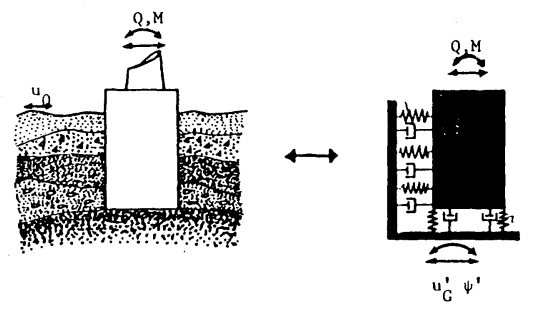

(a)

(b)

\section{図一1地震動を受ける基礎-地盤系とそのばね-質量モデル}

* 正会員 工博 宮崎大学助教授 工学部土木工学科 （下880 宮崎市霧島 1-1-1）

** 正会員 工博 東京大学名誉教授, 埼玉大学教授 建設 工学科 ( 1338 浦和市下大久保 255)

*** 正会員 Ph.D. 東京大学教授 生産技術研究所

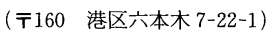

いなければならない.このような構造物としては地下式 タンク等が考えられるが, たとえば, 図一2 23 は浜田 博士による地下タンクとその周辺地盤の地震観測記録と そのパワースペクトルを示す4). 地表の波形 A 1 X ${ }^{4} 4^{\prime}$ $\mathrm{X}$ に比べるとタンクの応答加速度波形 $\mathrm{A} 2 \mathrm{X}, \mathrm{A} 7 \mathrm{X}$ には, 明らかに短周期成分が少ない。また，タンク上面の波形 は底面のものより大きいため, タンクは, 水平と回転の 連成運動を行っている.このタンクの応答波形がまさに 有効地震動で地表の波形とは異なる. 一般に, 地表の波 形に比べると, 地下数十 $\mathrm{m}$ 程度の波形は, その振幅が 小さい. したがって, 基礎底面と基礎上面との 2 点間の 地盤には相対変位が生じるが, 基礎周面と地盤の摩擦力 のために, 基礎はこの相対変位に追従して, 結局, 水平 と回転の運動をすることになる.このように基礎周辺地 盤の地震動が基礎の幾何学条件により拘束されて生じる 有効地震動の考え方は決して新しいものではないが，い まだに確定した考え方もなく，研究が少ないのが現状で ある. 1969 年, 山原博士は初樭礎版による地震波 の入力損失を一種の数值フィルターとして考える論文を 発表した ${ }^{5)}$. その後, しばらく間をおくが, アメリカ合 衆国において，原子力発電所の耐震設計の問題とからん で,この種の研究が活発化する. たとえば, 1977 年, Newmark 博士らは, Holleywood Storage ビルの地震記 録を用いて，入力損失の実証を試みている ${ }^{6)}$.しかし， 

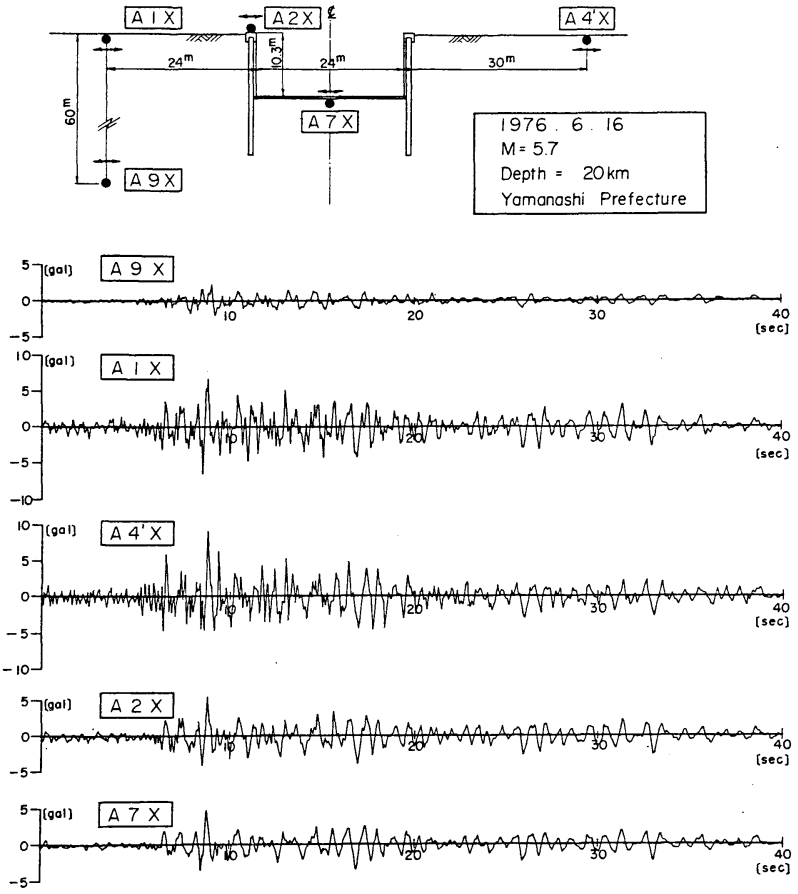

図一2 地下タンクと周辺地盤の加速度記録（浜田博士による）

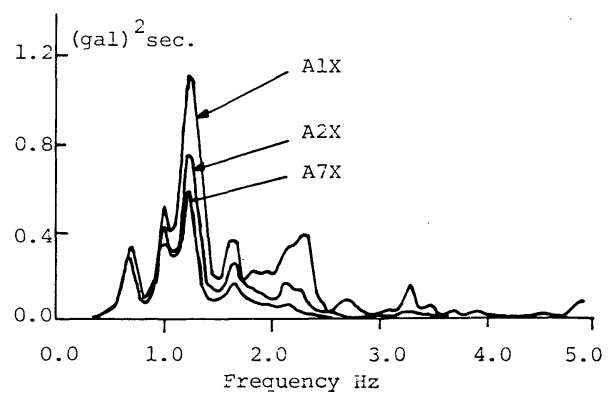

図一3 加速度波形のパワースペクトル

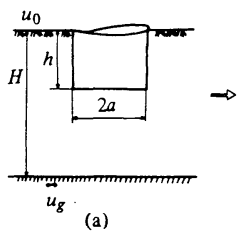

(a)

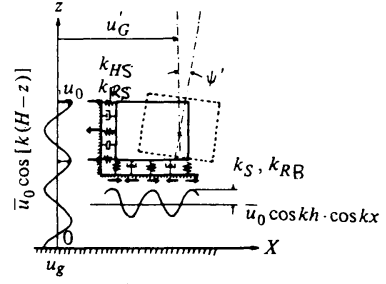

(b)

図一4 数学モデルと記号

アメリカをはじめ, 当時は, 有限要素法等を使った数值 シミュレーションによって地盤と構造物の動的相互作用 問題を解析することが主流であったこともあって，基礎 版の入力損失効果をどのようにモデルに組み込むか等, 地盤と構造物の動的相互作用問題との関係はあいまいで あった。しかし，1977 年，Kausel 博士らによる有限要 素法や7)，1978 年，1981 年，著者らによる弾性波動理 論を用いた定式化等 ${ }^{1)}$ (3) が発表されこの有効地震動の物 理的意味や動的相互作用問題における位置づけ等がしだ いに明確化してきている．最近では，わが国において， 原子力発電所の合理的耐震設計の問題にからみ，この問 題が実証的に研究され始めている ${ }^{81,9)}$.

そこで，本論文では，わが国の多くの地震観測デー夕 が有効に使われ有効地震動の特性が明らかにされ，これ を取り入れた耐震設計が確立されることを目標に，円筒 埋設剛体基礎に詨する有効地震動の計算式を提案する. 有限要素法の結果亡比較し, 本提案式の妥当性を確認し たあと,さらに多くの基礎-地盤系に対するパラメーター 解析を実施し, 有効地震動の簡略式を提案する.これら の計算式による有効地震動の妥当性を検証するために模 型地下タンクの実験や図一 2 に示した地下タンクの地震 記録との比較検討を行う。

\section{2. 有効地震動の計算式}

質量が零の基礎の地震応答値という定義に従って，図 一4(a) のような一様地盤中の基礎を考える. 地盤の動 きによって基礎は水平と回転の連成運動となるが，これ を図一4(b) のような数学モデルによって検討する.こ のモデルでは, 質量が零の基礎はばねとダッシュポット で支持され，これらの支点に地震動が入力される．基礎 側壁に作用する地震動は簡単のため表層地盤のせん断振 動で与えられるものとする.すなわち，振動数 $\omega$ の振 幅は, $z$ 点において ${ }^{2)}$,

$$
u(z)=\bar{u}_{0} \cos [k(H-z)] e^{i \omega t}
$$

ここに,

$$
k=\frac{\omega}{v_{s s} \sqrt{1+i 2 D_{s}}}
$$

こここに， $v_{s s}=$ 表層地盤のせん断波速度， $D_{s}=$ 表層地盤 材料の減衰定数, $i=\sqrt{-1}, \quad t=$ 時間.

式（１）で $\bar{u}_{0}$ は自然地盤の地表面での振幅である.他方， 基礎底面に作用する地震動は, 速度 $V$ で $x$ 軸正負の方 向に伝播する波動を考えて，次式のものを仮定する。

$$
u_{h}(x)=\bar{u}_{0} \cos k h \cos \frac{\omega x}{V} e^{i \omega t} \text {. }
$$

式（3）によると, 基礎底面に沿う地震動は, cos $\omega x / V$ によって位相が変わることになる.この位相変 化については, 不明な点が多く, 今後, 物理的意味を含 めて研究しなければならないが，後に示すように，図一 4 のモデルに鉛直下方から地震波を入力する場合につい て, FEM モデルにより計算した結果との比較によると 
$V=v_{s s}$ とすると, 両者がよく一致するため, 式 ( 3 ) ではこの值を使用する.

図一4のばねとダッシュポットとしては, 次式の複素 ばね係数を用いる.

$$
\begin{aligned}
& k_{H}=G_{s}\left(s_{u 1}+i s_{u 2}\right) \cdots \cdots \cdots \text { 基礎側面の水平 } \\
& k_{R S}=G_{s} a^{2}\left(s_{r 1}+i s_{r 2}\right) \cdots \cdots \text { 基礎側面の回転 } \\
& k_{s}=G a\left(c_{u 1}+i c_{u 2}\right) \cdots \cdots \cdots \text { 基礎底面の水平 } \\
& k_{R B}=G a^{3}\left(c_{r 1}+i c_{r 2}\right) \cdots \cdots \text { 基礎底面の回転 } \\
& G=\rho v_{s}^{2} \quad G_{s}=\rho_{s} v_{s s}^{2}
\end{aligned}
$$

式（4）の複素ばね係数は基礎に単位振幅の変位を与え るために必要な力として求められるが31, ここに， $G$, $G_{s}$ はそれぞれ基礎底面および基礎側面の接する地盤の せん断弾性係数， $\rho ， \rho_{s}$ は同じように地盤の密度である. また， $s_{i j}, c_{i j}$ は無次元複素ばね係数とよばれ，具体的 な計算式は文献 10）に与えられる.

式 (1)〜（4）で与えられる地震入力と複素ばね係数 を用いると，図一4(b) の力のつり合いより，質量が零 の基礎の地震応答值である有効地震動は次式で与えられ る.

$$
\left[\begin{array}{ll}
K_{11} & K_{12} \\
K_{12} & K_{22}
\end{array}\right]\left\{\begin{array}{l}
u_{G}^{\prime} \\
\varphi^{\prime}
\end{array}\right\}=\left\{\begin{array}{l}
D_{1} \\
D_{2}
\end{array}\right\} \bar{u}_{0} e^{i \omega t}
$$

ここに， $u_{G}^{\prime}, \varphi^{\prime}$ は有効地震動の水平および回転成分で あり， $K_{i j}$ は基礎の複素ばね係数で次式のように与えら れる。

$$
\left.\begin{array}{l}
K_{11}=K_{x x}+i \omega C_{x x} \\
K_{12}=K_{x r}+i \omega C_{x r} \\
K_{22}=K_{r r}+i \omega C_{r r}
\end{array}\right\}
$$

式（6）で，動的ばね係数は,

$$
\begin{aligned}
K_{x x}= & G a\left(c_{u 1}+\frac{G_{s}}{G} \delta s_{u 1}\right) \\
K_{r r}= & G a^{3}\left[c_{r 1}+\left(\frac{Z_{c}}{a}\right)^{2} c_{u 1}+\frac{G_{s}}{G} \delta s_{r 1}\right. \\
& \left.+\frac{G_{s}}{G} \delta\left(\frac{\delta^{2}}{3}+\frac{Z_{c}^{2}}{a^{2}}-\delta \frac{Z_{c}}{a}\right) s_{u 1}\right] \\
K_{x r}= & -G a\left[Z_{c} c_{u 1}+\frac{G_{s}}{G} \delta\left(Z_{c}-\frac{h}{2}\right) s_{u 1}\right]
\end{aligned}
$$

一方, 動的減衰係数は

$$
\begin{aligned}
C_{x x}= & \frac{G a}{\omega}\left(c_{u 2}+\frac{G_{s}}{G} \delta s_{u 2}\right) \\
C_{r r}= & \frac{G a^{3}}{\omega}\left[c_{r 2}+\left(\frac{Z_{c}}{a}\right)^{2} c_{u 2}+\frac{G_{s}}{G} \delta s_{r 2}\right. \\
& \left.+\frac{G_{s}}{G} \delta\left(\frac{\delta^{2}}{3}+\frac{Z_{c}^{2}}{a^{2}}-\delta \frac{Z_{c}}{a}\right) s_{u 2}\right] \\
C_{x r}= & -\frac{G a}{\omega}\left[Z_{c} c_{u 2}+\frac{G_{s}}{G} \delta\left(Z_{c}-\frac{h}{2}\right) s_{u 2}\right]
\end{aligned}
$$

ここに, $\delta=h / a, Z_{c}=$ 基礎底面から着目点までの距離 である.また， $D_{1}, D_{2}$ は次式で与えられる.

$$
\begin{aligned}
D_{1}= & k_{H} h \frac{\sin k h}{k h}+k_{s} \frac{\sin 2 k a}{2 k a} \cos k h \\
D_{2}= & -k_{H} h Z_{c} \frac{\sin k h}{k h}-k_{H} h^{2} \frac{\cos k h-1}{(k h)^{2}} \\
& -k_{S} Z_{c} \frac{\sin 2 k a}{2 k a} \cos k h
\end{aligned}
$$

式（5）は有効地震動を与えるが，図一4(b) のような 簡単な数学モデルによる結果であるため, もつと厳密な モデルから得られる結果と比較しておく必要がある. 図 -5〜11 の破線は表一1 の基礎-地盤系について軸対称有 限要素法によって質量零の基礎の地震応答値を計算した ものである ${ }^{2), 7)}$. これらの図では，基礎底面 $Z_{c}=0$ にお ける水平成分 $\bar{u}_{0}^{\prime}$ 亡回転成分 $\bar{\varphi}^{\prime}$ の振幅を自然地盤の地表 の応答振幅 $\bar{u}_{0}$ で除した $\bar{u}_{0}^{\prime} / \bar{u}_{0}, \bar{\varphi}^{\prime} a / \bar{u}_{0}$ の值が示されて いる．横軸は地震動の振動数で $\omega h / v_{s s}$ としてプロット されている. 以後このような図を有効地震動の伝達関数 とよぶ.このような有限要素法による伝達関数と式 ( 5 ) の結果を比較したところ, 式（5）の水平成分は有限要 素法の結果とよく一致するが，回転成分では振幅が多少 大きく与えられた。そこで，回転成分では，スケーリン グ係数として，0.65を採用して，式 $(5)$ より，次式 のように基礎底面における有効地震動の計算式を求め た.

$$
\left.\begin{array}{l}
u_{0}^{\prime}=\left[\frac{D_{1} K_{22}-D_{2} K_{12}}{K_{11} K_{22}-K_{12}^{2}}\right] \bar{u}_{0} e^{i \omega t}, Z_{c}=0 \\
\varphi^{\prime}=0.65\left[\frac{D_{2} K_{11}-D_{1} K_{12}}{K_{11} K_{22}-K_{12}^{2}}\right] \bar{u}_{0} e^{i \omega t}, Z_{c}=0
\end{array}\right\}
$$

ここで, $D_{j}$ と $K_{i j}$ は式 $(7) \sim(9)$ で与えられる. 式 $(10)$ による伝達関数を図一5〜11 に一点鎖線で示す。細部に おいては, 違いがみられるが, 全体的に有限要素法の結 果とよく一致しているのが認められる.これらの結果に よると, 回転成分は振動数の増加とともに徐々に大きく なり $\omega h / v_{s s}=0.5 \pi$ 以降は波うちながらもほぼ一定の 值を示す。一方, 水平成分は振動数の増加とともに娍少 してゆき, 無次元振動数がこれも $0.5 \pi$ 以降は波うちな がらも一定の傾向を示している.

図一5〜11に示した結果をもとに, 式 (10) を使って, さらに, 原子力発電所や道路橋ケーソン基礎を対象に合 計 21 の基礎-地盤系に対して，有効地震動の伝達関数を 計算して ${ }^{2)}$ ，この結果を式 (11)，(12）のような伝達関 数にまとめた. 式（12）による伝達関数を図一5～11 に 実線で示す.この簡略式は, 図一5〜11 からもわかるよ うに伝達関数をやや大きめに評価するように決めている が, 各ケースにおいて, 全体的傾向は, よく一致してい るのが認められる.

CASE I : 基礎底面が堅固な基盤に設置され表層地 盤に埋設される場合 


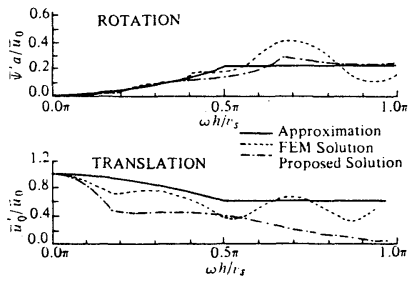

図-5 Case 1の伝達関数

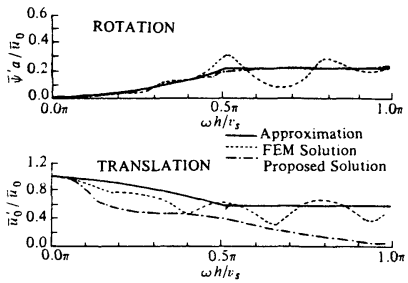

図-6 Case 2 の伝達関数

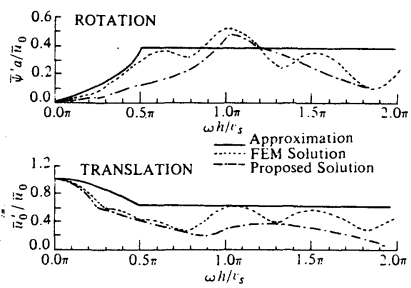

図一9 Case 5 の伝達関数

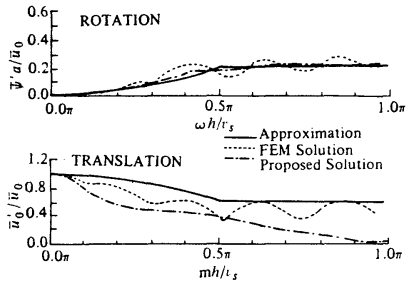

図一7 Case 3 の伝達関数

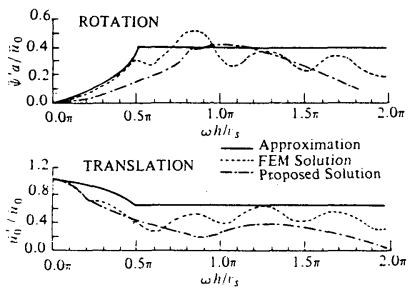

図-10 Case 6 の伝達関数

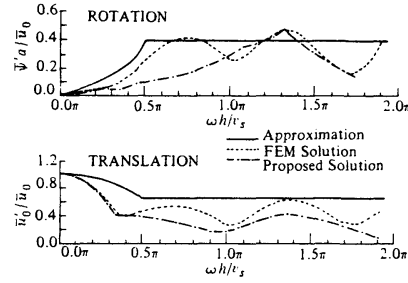

図一8 Case 4 の伝達関数

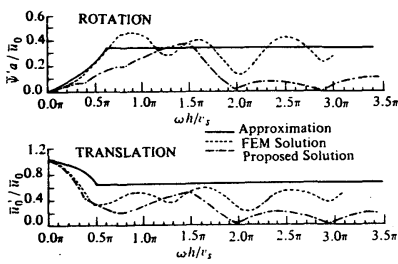

図一11 Case 7の伝達関数
水平成分は,

$$
\frac{\bar{u}_{0}^{\prime}}{\bar{u}_{0}}= \begin{cases}|\sin k h /(k h)| & 0 \leq k h \leq \pi / 2 \\ 0.63 & \pi / 2 \leq k h\end{cases}
$$

回転成分は,

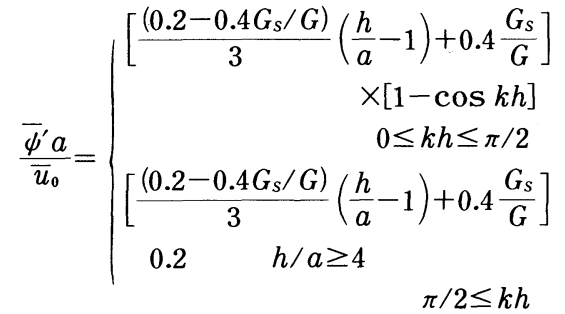

CASE II : 表層地盤の途中に基礎底面が設置される 場合

水平成分は,

$$
\frac{\bar{u}_{0}^{\prime}}{\bar{u}_{0}}= \begin{cases}|\sin k h /(k h)| & 0 \leq k h \leq \pi / 2 \\ 0.63 & \pi / 2 \leq k h\end{cases}
$$

回転成分は,

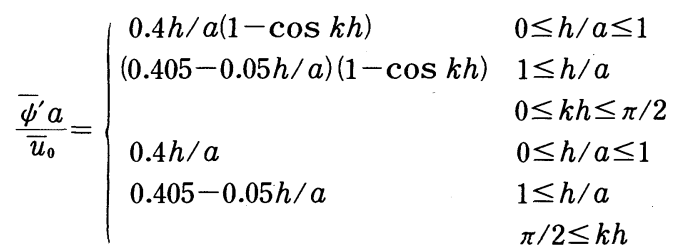

\section{3. 模型地下タンクの実験值との比較}

前章で求めた有効地震動の伝達関数の妥当性を検討す るために，模型地下タンクの実験值との比較を行う．模 型実験は地下タンクの地震時挙動を観測する目的で実施 されたものであるが，タンクの質量がきわめて小さいこ と, タンクの運動は巨視的には剛体運動であることのた めにこの実験結果はまた有効地震動の計測のためにも用 いることができる．この種の実験では，模型地盤の側方 境界の影響が問題となる場合が多いが，有効地震動の伝 達関数に関しては，この関数は地盤の応答と地下タンク の応答の比として与えられるため, 模型地盤の側方境界 の影響は少ないものと考えられる.

実験值は日本ガス協会 ${ }^{11)}$ と大林組技術研究所 ${ }^{12}$ の実施 したものを用いる．図一12と 13 に示すように，振動台 上にゴムと重合体で作った地下タンクと地盤をのせて， 種々の加振実験が行われた。ここでは, 正弦波加振によ る地表と地下タンクの応答振幅を用いて, タンク底面の 伝達関数を求めた. 地表の振幅は場所によって違うため に，地表の振幅とタンクの振幅の比として与えられる伝 達関数の值はばらつくが，これらを整理すると，図一14 と 15 のような伝達関数が得られた。これらの図には， 


\begin{tabular}{|l|l|c|c|c|}
\hline & Material & $\begin{array}{c}\text { Young's } \\
\text { Modulus } \\
E\left(\mathrm{~kg} / \mathrm{cm}^{2}\right)\end{array}$ & $\begin{array}{c}\text { Poisson's } \\
\text { Ratio }\end{array}$ & $\begin{array}{c}\text { Unit } \\
\text { Weight } \\
\left(\mathrm{g} / \mathrm{cm}^{3}\right)\end{array}$ \\
\hline Tank & Chloroprene & 92.0 & 0.34 & 1.26 \\
\hline Soil 1 & Polymer & 0.10 & 0.5 & 1.05 \\
Soil 2 & Polymer & 0.57 & 0.5 & 1.07 \\
Soil 3 & Polymer & 1.56 & 0.5 & 1.09 \\
\hline
\end{tabular}

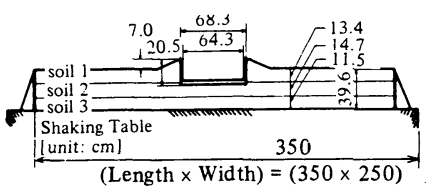

図一12 模型地下タンクと地盤 (実験 $1^{11)}$ )

\begin{tabular}{|c|c|c|c|c|}
\hline & Material & $\begin{array}{c}\text { Shear } \\
\text { Wave Vel. } \\
(\mathrm{m} / \mathrm{sec})\end{array}$ & $\begin{array}{c}\text { Damping } \\
\%\end{array}$ & $\begin{array}{c}\text { Unit } \\
\text { Weight } \\
\left(\mathrm{g} / \mathrm{cm}^{3}\right)\end{array}$ \\
\hline Tank & $\begin{array}{l}\text { Silicone } \\
\text { Rubber }\end{array}$ & $E=130 \mathrm{~kg} / \mathrm{cm}^{2}$ & & 1.26 \\
\hline Soil 1 & Polymer & 1.97 & 4.8 & 1.0 \\
Soil 2 & Polymer & 2.68 & 2.4 & 1.0 \\
Soil 3 & Polymer & 4.81 & 1.2 & 1.0 \\
\hline
\end{tabular}

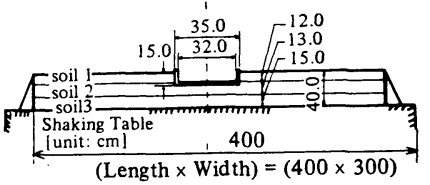

図一13模型地下タンクと地盤 (実験 $2^{12)}$ )

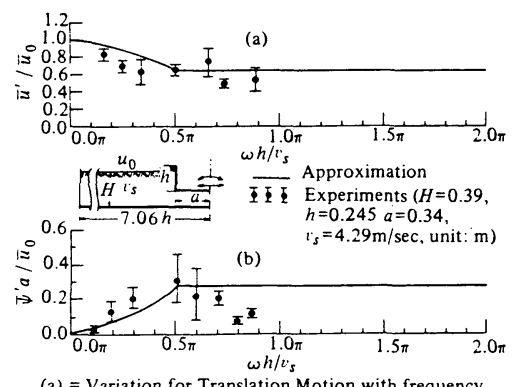

(a) = Variation for Translation Motion with frequency (b) = Variation for Rocking Motion with frequency

図一14 実験 1 の伝達関数との比較

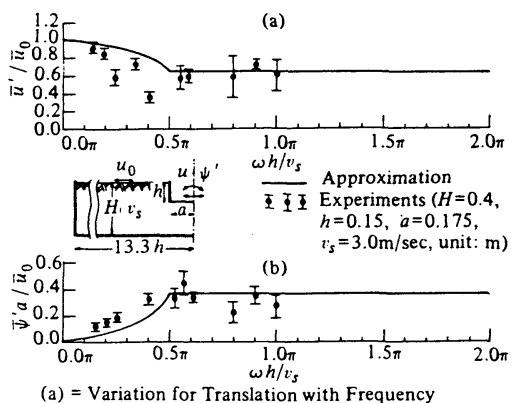

(b) = Variation for Rocking Motion with Frequency

図-15 実験 2 の伝達関数との比較
式（12）による伝達関数を実線で示すが，全体的傾向の よい一致が認められる。

\section{4. 実物地下タンクの地震観測結果との比較}

ここでは, 図一2 に示した地下タンクの地震観測結果 ${ }^{4}$ を使って，有効地震動の伝達関数について検討する.こ の地下タンクは, 図一16 に示すように内径 $24 \mathrm{~m}$, 深さ $10.3 \mathrm{~m}$ の円筒形状をした RC 構造で, 側壁は外側の地 中壁と内側のコンクリート壁の 2 重構造である. 地中壁 は 17 個の直線エレメントよりなりおのおの縦ジョイン トにより閉合されているが，内側のものはコンクリート で打継目なしに打設されている.タンク頂部は幅 $1.3 \mathrm{~m}$, 高さ $1.5 \mathrm{~m}$ のコンクリートリングにより補強されてい るが, 底版は $20 \mathrm{~cm}$ 厚のコンクリートスラブで側壁と は完全に分離されている.

この地下タンクの頂部と底版の加速度波形 A 2X, A7 Xおよび地表の A $1 \mathrm{X}$ （図一2参照）を用いて，タンク 底面における有効地震動の伝達関数 $\bar{u}_{0}^{\prime} / \bar{u}_{0}$ および, $\bar{\varphi}^{\prime} a / \bar{u}_{0}$ を計算したものを図一17に示す。このように観 測波形から求めた伝達関数もまたこれまでに有限要素法 や計算式から求めた伝達関数と同じ傾向を示しているの が認められる.

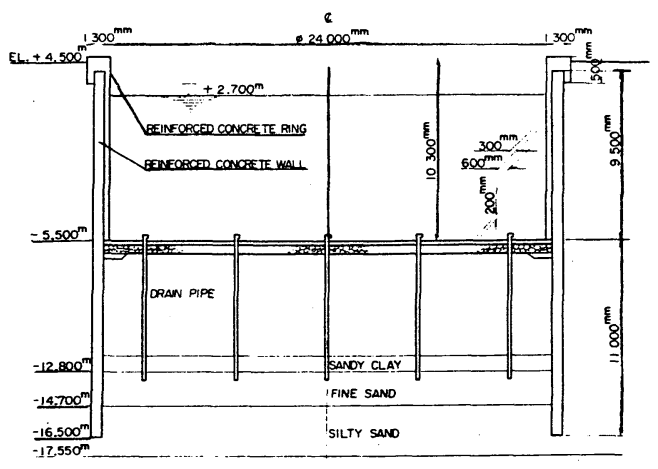

図一16 地下タンクの構造
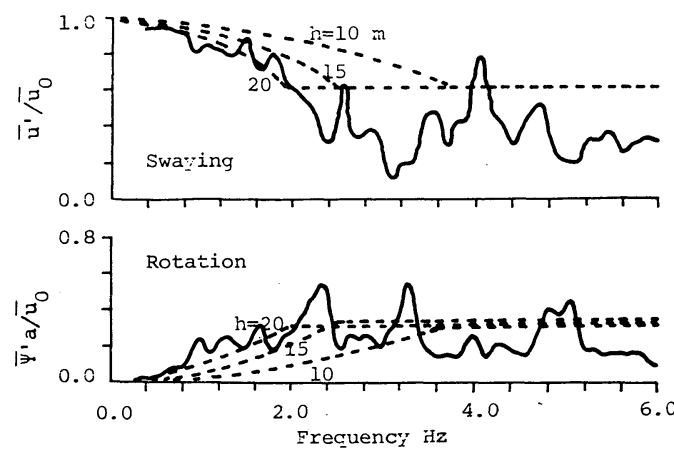

図一17 実物地下タンクの地震記録から求めた伝達関数（実線） と近似式 (点線) の比較 
次に近似式（12）との比較を行うが，上述したように この地下タンクは外側の地中壁が約 $20 \mathrm{~m}$ 深さまで打設 されている等これまでに計算で用いたような完全な円筒 タンクではない点に注意しておかなければならない。地 盤のせん断波速度とタンクの半径に関しては実測值を用 いて, $v_{s s}=150 \mathrm{~m} / \mathrm{s}, a=12.15 \mathrm{~m}$ とするが，埋設深さ $h$ については, 図一16を参考にして, $h=10,15,20 \mathrm{~m}$ の 3 種類を用いることとした。これらの定数を式 (12) に代入して伝達関数を計算したものを点線で図一17に 示すが，埋設深さを $15,20 \mathrm{~m}$ とした場合の方が実測結 果に近いようである. いずれにしても, 今後, 実測結果 の蓄積をはかり式 (10)〜 (12) の妥当性の検証や改良が 必要であろう。

\section{5. ま と め}

本論文は，円筒地中剛体基礎に対する有効地震動の計 算式とその妥当性について, 有限要素法や地下タンクの 模型実験結果およびタンクの地震観測結果を用いて，検 討したものである．結果は以下のように要約できよう。

（1）有効地震動の物理的意味や定義に従って，これ の計算式を提案した。この計算式は，地盤の材料定数之 基礎-地盤系の幾何学定数（表層地盤の厚さ，基礎の半 径および埋設深さ) の関数として与えられる.

（2）この計算式による有効地震動では，自然地盤の 地震動に比べて，短周期成分の少ない波となっており， また，水平成分に加えて，回転成分が現われる。

（3）有限要素法や模型地下タンクの実験資料および 地下タンクの地震観測資料から, 有効地震動を計算し, 計算式によるものとの比較では，細部は一致しないが, 全体的傾向はきわめてよく一致した．今後，実測記録の 蓄積と本論文で示したような方法によってこれらの計算 式の妥当性の検証や改良が必要であるが，いずれにして も，有効地震動の物理的意味や基礎と地盤の地震時相互 作用問題における位置づけが明らかとなっており，また， 有効地震動の特性も上述したようにはっきりしてきてい る. 特に, 自然地盤の地震動に比べて短周期成分が少な いこと等の特性は，現在，一般によく用いられているよ うに自然地盤の地震動を使った構造物の地震応答計算結 果に比べると，有効地震動による応答計算結果が短周期 領域でかなり低減されることを意味している。このよう な特性をもつ有効地震動であるが, 実務設計においても,
今後, もっと積極的に有効地震動が検討されてよいよう に思われる．なお，利用した資料は，本来，地下タンク の地震時挙動の研究目的に, それぞれ, 浜田政則博士 (東 海大学), 後藤洋三氏（大林組技術研究所）および日本 ガス協会の関係諸氏らにより得られたものであるが，本 研究の目的を理解していただき，有効地震動の実証例の ために提供されたものである．記して感謝の意を表わす 次第である。

\section{参 考 文 献}

1）原田隆典・久保慶三郎・片山恒雄：地震動を受ける埋設 剛体基礎の運動方程式, 第 33 回土木学会年次講演 I - 230 , 1978.

2) Harada, T., Kubo, K. and Katayama, T. : Dynamic Soil-Structure Interaction Analysis by Continuum Formulation Method, 東京大学生産技術研究所報告, Vol. 29, No. 5, 1981.

3）原田隆典・久保慶三郎・片山恒雄：地中埋設剛体構造物 の地震応答解析モデルの考え方，土木学会論文報告集, 第 334 号, pp. 173 176， 1983.

4）浜用政則 : 大型地下タンクの地震時挙動の観測之解析, 土木学会論文報告集，第 273 号， 1978.

5）山原 浩：地震時の地動と地震波の入力損失, 日本建築 学会論文報告集, No. 165, 1969 およびNo. 167, 1970.

6) Newmark, N. M., Hall, W. J. and Morgan, J.R. : Comparison of Building Response and Free Field Motion in Earthquakes, 6th World Conference on Earthquake Engineering, 1977.

7) Kausel, E., Whitman, R. V., Elasabee, F. and Morray, J.P. : Dynamic Analysis of Embedded Structures, Proc. of 4th SMIRT, K 2/6, 1977.

8）沢田義博 - 矢島 浩 - 佐々木俊二 ・桜井彰雄 - 高橋 忠： 地震動に対する基礎の制震効果よその特性について，第 6 回日本地震工学シンポジウム, pp. 1553 1560, 1982.

9）石井 清 - 小山和夫：地下タンクの常時微動測定による 入力損失効果の検討, 土木学会論文報告集, 第 339 号, pp. $51 \sim 57,1983$.

10）原田隆典 - 久保慶三郎 - 片山恒雄 - 広瀬利光：地中円筒 剛体基礎の動的ば颣係数と減衰係数, 土木学会論文報告 集，第 339 号，pp. 79 88，1983.

11) 一日本ガス協会, 液体天然ガス用保案委員会: 液化ガス用 貯槽の保案調査について, 1979.

12）後藤洋三・白砂 健：沖積地盤における群地下タンクの 地震応答特性, 第 5 回日本地震工学シンポジウム, pp. $977 \sim 984,1978$.

(1984.12.26 • 受付) 